\title{
Methaemoglobinaemia and the radical curative efficacy of 8-aminoquinoline antimalarials
}

\author{
Nicholas White ${ }^{1}$, James Watson ${ }^{2}$, and Kevin Baird ${ }^{3}$ \\ ${ }^{1}$ Faculty of Tropical Medicine, Mahidol Iniversity \\ ${ }^{2}$ Mahidol University Faculty of Tropical Medicine \\ ${ }^{3}$ Eijkman Institute for Molecular Biology
}

December 14, 2021

\begin{abstract}
Methaemoglobin results from the oxidation of ferrous to ferric iron in the centre of the haem moeity of haemoglobin. The production of dose-dependent methaemoglobinaemia by 8 -aminoquinoline antimalarial drugs appears to be associated with, but is not directly linked to therapeutic efficacy against latent vivax and ovale malarias. Iatrogenic methaemoglobinaemia may be a useful pharmacodynamic measure in 8-aminoquinoline drug and dose optimization.
\end{abstract}

\section{Methaemoglobinaemia and the radical curative efficacy of 8-aminoquinoline antimalarials}

Nicholas J White ${ }^{1,2}$, James A Watson ${ }^{1,2}$, J Kevin Baird ${ }^{2,3}$

1. Mahidol Oxford Research Unit, Faculty of Tropical Medicine, Mahidol University, Bangkok, Thailand

2. Centre for Tropical Medicine and Global Health, Nuffield Department of Medicine, University of Oxford, Oxford, United Kingdom.

3. Eijkman-Oxford Clinical Research Unit, Eijkman Institute for Molecular Biology, Jakarta, Indonesia

* WHAT IS ALREADY KNOWN ABOUT THIS SUBJECT

The 8-aminoquinoline antimalarials are the only drugs which can prevent relapses of $P$. vivax and $P$. ovale malaria (radical cure) but no pharmacodynamic correlates of this activity have been identified. The 8aminoquinolines cause dose dependent methaemoglobinaemia, and they cause haemolysis in patients with G6PD deficiency.

* WHAT THIS STUDY ADDS

Review of data accrued over the past 70 years indicates that methaemoglobinaemia is correlated with radical curative activity. Methaemoglobinaemia could be used to optimize 8-aminoquinoline antimalarial dose regimens.

\begin{abstract}
Methaemoglobin results from the oxidation of ferrous to ferric iron in the centre of the haem moeity of haemoglobin. The production of dose-dependent methaemoglobinaemia by 8 -aminoquinoline antimalarial drugs appears to be associated with, but is not directly linked to therapeutic efficacy against latent vivax and ovale malarias. Iatrogenic methaemoglobinaemia may be a useful pharmacodynamic measure in 8aminoquinoline drug and dose optimization.
\end{abstract}

\section{Introduction}


Hepatic latency in vivax and ovale malarias requires treatment with 8-aminoquinoline drugs in order to prevent recurrent attacks called relapses (a therapy called radical cure). The first 8-aminoquinoline (variously named plasmoquine, plasmochin, or pamaquine) was discovered nearly one hundred years ago. Within four years of the reported discovery and introduction, Sinton and colleagues working in Northern India discovered that the combination of quinine and plasmoquine was effective in preventing late recurrences (presumed relapses) of Plasmodium vivax malaria $(1,2)$. This efficacy against late attacks of vivax malaria was very slow to be accepted by international authorities (notably the malaria commission of the League of Nations) and malaria experts. Plasmoquine was not well tolerated at the doses required for radical cureabdominal pain and vomiting were dose limiting, and "cyanosis" was noted with higher doses (3-5). It was also observed that about $10 \%$ of patients of African or Asian origin developed significant haemolytic anaemia (5). The cyanosis following pamaquine therapy was caused by methaemoglobinaemia, and the sporadic severe haemolytic anaemia was later identified as resulting from the oxidant drug susceptibility of erythrocytes with reduced glucose-6-phosphate dehydrogenase (G6PD) activity. During the Second World War recurrent vivax malaria in the Indo-Burman and Pacific theatres of war was a major threat to soldiers on both sides. An intensive research effort, based in the United States, set out to discover more effective and better tolerated 8-aminoquinolines. Pharmacometric studies in volunteers infected with P. vivax (notably the frequent relapse Chesson strain originating in New Guinea) and in rhesus monkeys infected with P. cynomolgi continued after the end of the Second World War, and ultimately led to the replacement of pamaquine by primaquine in 1951 during the Korean war (6). These large and detailed pioneering volunteer studies recorded a wealth of valuable information.

\section{Relapse in experimental and naturally acquired vivax malaria}

In the experimental malaria studies, non-immune volunteers were infected either by blood taken from a malaria patient or by infected mosquito bites. The volunteers were then observed daily, usually for at least one year (many were prison volunteers). Building on the extensive experiences of malariatherapy of neurosyphilis during the early to mid- $20^{\text {th }}$ century, which had refined and standardized the methods of infection and clinical management, at least five and usually ten infected (i.e. sporozoite positive) laboratory reared anopheline mosquitoes were used to initiate the infection. This ensured a substantial sporozoite inoculum was delivered to the recipient. With the Chesson strain of $P$. vivax the consequent early relapse rate was $100 \%(7)$.

This high relapse rate in experimental malaria should be contrasted with natural infections in which a single mosquito, with an infection of variable age (and thus transmission potential), infects an individual who may already have significant natural immunity dampening illness (8). This distinction is important because it has a substantial bearing on the binary outcome therapeutic response to 8-aminoquinolines i.e. relapse or no relapse. Very high relapse rates usually result from multiple inoculations (e.g. in soldiers fighting in the Pacific theatre of World War 2) (9). Overall, the relapse prevention (i.e. radical curative) efficacy of 8 -aminoquinolines was substantially better in clinical practice compared with the stern test applied in the volunteer infections. For example, the combination of quinine and plasmoquine at doses $>30 \mathrm{mg}$ base/day was considered highly effective in preventing relapse in clinical studies in endemic areas, but doses below $90 \mathrm{mg}$ base/day were relatively ineffective in the experimental challenge model $(2,3,10,11)$. Thus, to compare radical curative efficacies it is necessary to consider both drug dosage, and thus exposure, and also the likely hypnozoite burden (12).

\section{Predictors of relapse}

Several different factors determine whether vivax or ovale malarias will relapse. The hypnozoite burden, geographic origin (i.e. "strain"), and degree of immunity are all important determinants. Liver stage immunity may affect hepatic schizont development and blood stage immunity suppresses the relapse parasitaemia to an extent that it is asymptomatic, subpatent, or both $(13,14)$. Although there is no evidence of acquired 8-aminoquinoline resistance in hypnozoites, parasites do differ in intrinsic susceptibility. For example, the long latency $P$. vivax "strains" prevalent in temperate regions are more susceptible to 8-aminoquinolines than tropical frequent relapse strains, and P. vivax parasites in SE Asia and Oceania appear to be less susceptible 
(i.e. require a larger primaquine dosage) than other tropical "strains" (15).

From a therapeutic perspective exposure to the biologically active metabolites of the 8-aminoquinoline is the critical factor determining relapse prevention (radical cure) efficacy $(16,17)$. This exposure results from the total dose absorbed, and the degree of biotransformation. Patients with cytochrome P450 2D6 polymorphisms conferring reduced function have reduced production of primaquine's bioactive metabolite(s) and correspondingly reduced radical curative efficacy $(18,19)$. The oxidative activity of the 8 -aminoquinoline treatment is also reflected in the intraerythrocytic concentrations of methaemoglobin. The association of methaemoglobinaemia with radical curative efficacy of 8-aminoquinolines is discussed.

\section{Methaemoglobinaemia}

Methaemoglobin results when the haem iron in haemoglobin is converted from the ferrous state $\left(\mathrm{Fe}^{++}\right)$, the reduced form, to the $\left(\mathrm{Fe}^{+++}\right)$ferric ion, the oxidized form (20). This process is coupled to redox cycles in the red cell. In the main cycle, driven by the NAD-cytochrome b5 reductase (the main methaemoglobin reductase), haemoglobin and methaemoglobin are cycled (Figure 1). In the second, a cell redox cycle system is driven by the oxidation of haemoglobin, with methaemoglobin as the product. Although the main enzyme responsible for intraerythrocytic methaemoglobin reduction is the NADH-cytochrome b5-reductase, there are alternative pathways. These include an NADPH-dependent methaemoglobin reductase (which has substantially reduced activity in G6PD deficiency), and direct reduction by intracellular ascorbate and glutathione (Figure 1). Methaemoglobin reduction is a first order process. Under normal steady state conditions approximately $3 \%$ of the body's haemoglobin is oxidized each day to methaemoglobin but, because of back-conversion, the average proportion of methaemoglobin is less than $2 \%$ of the corresponding haemoglobin concentration. Numerous factors influence this balance (including foods, drugs, exercise, smoking, hypoxia).

Methaemoglobin is a dark blue-brown colour compared with the bright red of oxygenated haemoglobin, so the skin colouration in methaemoglobinaemia resembles that in cyanosis caused by increased concentrations of deoxygenated haemoglobin. Methaemoglobin has a distinct spectrum from haemoglobin. Methaemoglobinaemia can be measured by spectrophotometry of fresh blood samples in the laboratory or, utilizing the same principle, by continuous transcutaneous oximetry devices. During exposure to the oxidizing agent methaemoglobinaemia increases, although there is substantial interindividual variation in iatrogenic methaemoglobinaemia with a skew distribution of steady state values. Interquartile ranges typically extend from approximately 60 to $140 \%$ of the median values and, for a given drug exposure, individual values can range tenfold in large series. With daily primaquine dosing methaemoglobinaemia has an estimated elimination half-life of approximately 1.5 days (Figure 2) i.e. $90 \%$ of the new steady state is reached in approximately 6 days.

Several different oxidant chemicals and drugs can cause methaemoglobinaemia. Although methaemoglobin production (i.e. haem oxidation) by 8 -aminoquinolines is generally considered not to lie in the causal pathway to haemolysis or antimalarial activity (26), it does provide an approximate correlate of these activities within the 8-aminoquinoline class. Under the rigorous test of the experimental challenge studies conducted in the USA in the late 1940s and early 1950s drugs, or drug concentrations, which produced less than $6 \%$ steady state methaemoglobinaemia were associated with sub-optimal radical cure rates (23-25) (Figure 3). As for iatrogenic haemolysis, there is a slight delay before intraerythrocytic methaemoglobin levels begin to rise following 8-aminoquinoline administration. This presumably reflects depletion of the oxidant defences (notably reduced glutathione) (27). In a large recent study of vivax malaria conducted on the Thailand-Myanmar border the relationships between primaquine and carboxyprimaquine plasma concentrations, relapses, CYP2D6 polymorphisms and methaemoglobinaemia were investigated. After adjusting for age and partner drug, the day 7 concentrations of primaquine and carboxyprimaquine were not associated with the risk of recurrence, but a $1 \%$ absolute increase in day 7 methemoglobin was associated with a hazard ratio for recurrence of 0.9 (95\% CI: 0.85-0.99, $\mathrm{p}=0.02)(28)$.

Tafenoquine is a slowly eliminated 8-aminoquinoline which has been introduced recently. It is notable that the currently recommended dose of tafenoquine (adult dose $300 \mathrm{mg}$ ), which provides radical cure rates which 
are inferior to the lower dose of primaquine (total dose $3.5 \mathrm{mg} / \mathrm{kg}$ ) in South-East Asia (29), is associated with methaemoglobin concentrations which are less than half those associated with the lower dose primaquine regimen $(30,31)$ (Figure 4).

\section{Drug interactions}

The 8-aminoquinolines have important pharmacokinetic and pharmacodynamic interactions with other structurally related antimalarial drugs. Coadministration of mepacrine (atebrin, quinacrine) substantially increases plasma concentrations of pamaquine and also reduces tolerability. It substantially increases methaemoglobinaemia associated with pamaquine (33). Chloroquine, piperaquine and pyronaridine all increase plasma concentrations of primaquine by approximately $20 \%$, but they do not affect tolerability (34). Pamaquine and primaquine radical curative activity is increased by concomitant (but not sequential) administration with quinine $(35,36)$. Chloroquine has also been shown to potentiate the radical curative efficacy of primaquine. During the clinical development of primaquine it was observed that coadministration of primaquine with quinine or chloroquine attenuated the consequent methaemoglobinaemia. This was not observed in comparable studies with pamaquine (plasmoquine) (Figure 5).

However larger, more recent, studies have not confirmed this early finding (Figure 6). They do not suggest any substantial differences between methaemoglobin levels with or without concomitant medicines (quinine, chloroquine, artesunate, artesunate-pyronaridine, dihydroartemisinin-piperaquine have all been evaluated), nor do they suggest differences between methemoglobin levels in the treatment of malaria (in which steady state methaemoglobin levels are reached well after resolution of symptoms), or in healthy subjects. Thus the impact of blood schizontocides on 8-aminoquinoline induced methaemoglobineamia is specific to the drugs and is not a general class effect.

\section{Methaemoglobinaemia and G6PD deficiency}

The discrepancy between 8-aminoquinoline haemolytic toxicity and methaemoglobinemia has been noted widely (26). In the research which led to registration of primaquine, Edgcomb et al (24) noted no correlation between haemolysis and methaemoglobinaemia following pamaquine or primaquine. The erythrocytes in G6PD deficiency have a reduced ability to reduce methaemoglobin in the presence of "electron-donors", such as the bioactive metabolites of primaquine or methylene blue (this is the basis of the methylene blue methaemoglobin reduction test developed to diagnose G6PD deficiency). This is because of the reduced intraerythrocytic activity of the NADPH dependent methemoglobin reductase. Brewer et al showed that whereas G6PD deficient individuals had increased levels of methaemoglobinaemia following oral sodium nitrite (an oxidizing agent which does not cause haemolysis), they haddecreased levels of methaemoglobinemia following primaquine (26) (Figure 7). This apparent paradox was explained by the iatrogenic haemolysis of the older erythrocytes which contained the highest concentrations of methaemoglobin. Other mechanisms are also possible, such as the sequestration of the primaquine oxidant metabolites in the oxidized haemoglobin Heinz bodies. The mechanism of 8-aminoquinoline haemolytic toxicity has not been explained satisfactorily but clearly involves more than broad oxidant stress.

\section{Conclusions}

Methaemoglobinaemia is associated with exposure to therapeutic doses of 8-aminoquinoline drugs. The proportion of methaemoglobin to haemoglobin correlates with the efficacy of anti-relapse therapy, but methaemoglobin appears to be uninvolved directly either in that activity or in haemolytic toxicity in G6PDdeficient patients. This suggests that the oxidative processes which result in methaemoglobinaemia are necessary, but they are not sufficient, for the radical curative activity of the 8-aminoquinoline antimalarial drugs. Although there is substantial inter-individual variation in iatrogenic methaemoglobinaemia, the overall clinical data suggest that methaemoglobinaemia is a pharmacodynamic correlate of radical curative activity. Measurement of methaemoglobinaemia might be useful in drug screening and dose evaluation.

Acknowledgements: We are very grateful to our many colleagues who have contributed extensively to the clinical studies. 
Declaration of Interests. We have no conflicts of interest.

Ethics approval and consent to participate. Not relevant.

Availability of data and material : All data used are available from the original publications.

Funding : Wellcome Trust

\section{References}

1. Sinton JA, Bird W: Studies in malaria with special reference to treatment; plasmoquine in treatment of malaria. Indian J Med Research 1928, 16: 159.

2. Sinton JA, Smith S, Potinger D. Studies in malaria, with special reference to treatment. XII. Further researches into treatment of chronic benign tertian malaria with plasmoquine and quinine. Indian $\mathrm{J}$ Med Res. 1930; 17: 793.

3. Orachowatz D. Toxicity, cyanosis induced by plasmochin treatment of malaria. Arch f Schiffs u Tropen Hyg 1928; 32: 119-21.

4. Hardgrove M, Applebaum IL. Plasmochin toxicity; analysis of 258 cases. Ann Intern Med. 1946 Jul;25:103-12.

5. Recht J, Ashley EA, White NJ. Safety of 8-aminoquinoline antimalarial medicines. Geneva, World Health Organization, 2014.

6. Baird JK. 8-Aminoquinoline therapy for latent malaria. Clin Microbiol Rev. 2019; 32: e00011-19.

7. Alving AS, Craige B, Pullman TN, Whorton CM, Jones R, Eichelberger L. Procedures used at Stateville Penitentiary for the testing of potential antimalarial agents. J Clin Invest 1948; 27: Suppl 2.

8. Boyd MF. The influence of sporozoite dosage in vivax malaria, Am J Trop Med. 1940; 20: $279-86$.

9. Hill E, Amatuzio DS. Southwest Pacific vivax malaria; clinical features and observations concerning duration of clinical activity. Am J Trop Med Hyg. 1949; 29: 203-14.

10. Most H, Kane CA, Lavietes PH, London IM, Schroeder EF, Hayman DM. Combined quinineplasmochin treatment of vivax malaria; effect of relapse rate. Am J Med Sci. 1946; 212: 550-60.

11. Craige B, Jones R, Whorton M, Pullman TN, Alving AS, Eichelberger L. Clinical standardization of Pamaquin (Plasmochin) in mosquito-induced vivax malaria, Chesson strain, a preliminary report. J Clin Invest 1948; 27: 309-315

12. White NJ. Anti-malarial drug effects on parasite dynamics in vivax malaria. Malar J. 2021; 20 : 161.

13. Christianson HB, Gordon HH, Daniels WB, Lippincott SW. Afebrile parasitemia in imported vivax malaria. Am J Publ Hlth 1946; 36: 759-761.

14. Chaumeau V, Kajeechiwa L, Fustec B, Landier J, Nyo SN, Hsel SN, Phatharakokordbun P, Kittiphanakun P, Nosten S, Thwin MM, Tun SW, Wiladphaingern J, Cottrell G, Parker DM, Minh MC, Kwansomboon N, Metaane S, Montazeau C, Kunjanwong K, Sawasdichai S, Andolina C, Ling C, Haohankhunnatham W, Christiensen P, Wanyatip S, Konghahong K, Cerqueira D, Imwong M, Dondorp AM, Chareonviriyaphap T, White NJ, Nosten FH, Corbel V. The contribution of asymptomatic Plasmodium infections to the transmission of malaria in Kayin state, Myanmar. J Infect Dis 2019; 219:1499-1509.

15. Alving AS, Hankey DD, Coatney GR, Jones R Jr, Coker WG, Garrison PL, Donovan WN. Korean vivax malaria. II. Curative treatment with pamaquine and primaquine. Am J Trop Med Hyg. 1953; 2: 970-6.

16. Pybus BS, Sousa JC, Jin X, Ferguson JA, Christian RE, Barnhart R, Vuong C, Sciotti RJ, Reichard GA, Kozar MP, Walker LA, Ohrt C, Melendez V. CYP450 phenotyping and accurate mass identification of metabolites of the 8-aminoquinoline, anti-malarial drug primaquine. Malar J. 2012; 11: 259.

17. Camarda G, Jirawatcharadech P, Priestley RS, Saif A, March S, Wong MHL, Leung S, Miller AB, Baker DA, Alano P, Paine MJI, Bhatia SN, O’Neill PM, Ward SA, Biagini GA. Antimalarial activity of primaquine operates via a two-step biochemical relay. Nat Commun. 2019 ;10: e3226.

18. Bennett JW, Pybus BS, Yadava A, Tosh D, Sousa JC, McCarthy WF, Deye G, Melendez V, Ockenhouse CF. Primaquine failure and cytochrome P-450 2D6 in Plasmodium vivax malaria. N Engl J Med. 2013; 369:1381-2. 
19. Baird JK, Louisa M, Noviyanti R, Ekawati L, Elyazar I, Subekti D, Chand K, Gayatri A, Instiaty, Soebianto S, Crenna-Darusallam C, Djoko D, Hasto BD, Meriyenes D, Wesche D, Nelwan EJ, Sutanto I, Sudoyo H, Setiabudy R. Association of Impaired Cytochrome P450 2D6 Activity Genotype and Phenotype with Therapeutic Efficacy of Primaquine Treatment for Latent Plasmodium vivax Malaria. JAMA Netw Open. 2018;1:e181449.

20. Umbreit J. Methemoglobin-it's not just blue: a concise review. Am J Hematol. 2007; 82: 134-44.

21. Sutanto I, Tjahjono B, Basri H, Taylor WR, Putri FA, Meilia RA, Setiabudy R, Nurleila S, Ekawati LL, Elyazar I, Farrar J, Sudoyo H, Baird JK. Randomized, open-label trial of primaquine against vivax malaria relapse in Indonesia. Antimicrob Agents Chemother. 2013; 57: 1128-35.

22. Chu CS, Phyo AP, Turner C, Win HH, Poe NP, Yotyingaphiram W, Thinraow S, Wilairisak P, Raksapraidee R, Carrara VI, Paw MK, Wiladphaingern J, Proux S, Bancone G, Sriprawat K, Lee SJ, Jeeyapant A, Watson J, Tarning J, Imwong M, Nosten F, White NJ. Chloroquine versus dihydroartemisininpiperaquine with standard high-dose primaquine given either for 7 days or 14 days in Plasmodium vivax malaria. Clin Infect Dis. 2019; 68: 1311-9.

23. Alving AS, Pullman TN, Craige B, Jones R, Whorton CM, Eichelberger L. The clinical trial of eighteen analogues of pamaquin (plasmochin) in vivax malaria (Chesson strain). J Clin Invest. 1948; 27: 34-45.

24. Edgcomb JH, Arnold J, Yount EH, Alving AS, Eichelberger L, Jeffery G, et al. Primaquine, SN 13272, a new curative agent in vivax malaria; a preliminary report. J Natl Malar Soc. 1950; 9: 285-92.

25. Cooper WC, Myatt AV, Hernandez T, Jeffery GM, Coatney GR. Studies in human malaria. XXXI. Comparison of primaquine, isopentaquine, SN-3883, and pamaquine as curative agents against Chesson strain vivax malaria. Am J Trop Med Hyg 1953; 2: 949-57.

26. Brewer GJ, Tarlov AR, Kellermeyer RW, Alving AS. The hemolytic effect of primaquine. XV. Role of methemoglobin. J Lab Clin Med 1962; 59: 905-17.

27. Beutler E. G6PD deficiency. Blood. 1994; 84: 3613-36.

28. Chu CS, Watson JA, Phyo AP, Win HH, Yotyingaphiram W, Thinraow S, Soe NL, Aung AA, Wilaisrisak P, Kraft K, Imwong M, Hanpithakpong W, Blessborn D, Tarning J, Proux S, Ling C, Nosten FH, White NJ. Determinants of primaquine and carboxyprimaquine exposures in children and adults with Plasmodium vivax malaria. Antimicrob Agents Chemother. 2021:AAC0130221. doi:10.1128/AAC.01302-21.

29. Llanos-Cuentas A, Lacerda MVG, Hien TT, Vélez ID, Namaik-Larp C, Chu CS, et al. Tafenoquine versus primaquine to prevent relapse of Plasmodium vivax malaria. N Engl J Med. 2019; 380: 229-41.

30. Walsh DS, Wilairatana P, Tang DB, Heppner DG Jr, Brewer TG, Krudsood S, Silachamroon U, Phumratanaprapin W, Siriyanonda D, Looareesuwan S. Randomized trial of 3-dose regimens of tafenoquine (WR238605) versus low-dose primaquine for preventing Plasmodium vivax malaria relapse. Clin Infect Dis. 2004; 39: 1095-103.

31. Llanos-Cuentas A, Lacerda MV, Rueangweerayut R, Krudsood S, Gupta SK, Kochar SK, Arthur P, Chuenchom N, Möhrle JJ, Duparc S, Ugwuegbulam C, Kleim JP, Carter N, Green JA, Kellam L. Tafenoquine plus chloroquine for the treatment and relapse prevention of Plasmodium vivax malaria (DETECTIVE): a multicentre, double-blind, randomised, phase $2 \mathrm{~b}$ dose-selection study. Lancet 2014; 383: 1049-58.

32. Nelwan EJ, Ekawati LL, Tjahjono B, Setiabudy R, Sutanto I, Chand K, Ekasari T, Djoko D, Basri H, Taylor WR, Duparc S, Subekti D, Elyazar I, Noviyanti R, Sudoyo H, Baird JK. Randomized trial of primaquine hypnozoitocidal efficacy when administered with artemisinin-combined blood schizontocides for radical cure of Plasmodium vivax in Indonesia. BMC Med. 2015; 13: 294.

33. Earle DP, Jr, Bigelow FS, Zubrod CH, Kane C. Studies on the chemotherapy of the human malarias. IX. Effect of pamaquine on the blood cells of man. J Clin Invest 1948; 27:121-129.

34. Chairat K, Jittamala P, Hanboonkunupakarn B, Pukrittayakamee S, Hanpithakpong W, Blessborn D, White NJ, Day NPJ, Tarning J. Enantiospecific pharmacokinetics and drug-drug interactions of primaquine and blood-stage antimalarial drugs. J Antimicrob Chemother 2018; 73: 3102-3113.

35. Berliner RW, Earle DP, Jr, Taggart JV, Welch WJ, Zubrod CG, Knowlton P, Atchley JA, Shannon JA. Studies on the chemotherapy of the human malarias. VII. The antimalarial activity of pamaquine. 
J Clin Invest 1948; 27:108 -113.

36. Alving AS, Arnold J, Hockwald RS, Clayman CB, Dern RJ, Beutler E, Flanagan CL. Potentiation of the curative action of primaquine in vivax malaria by quinine and chloroquine. J Lab Clin Med 1955; 46:301-306.

37. Clayman CB, Arnold J, Hockwald RS, Yount EH, Edgcomb JH, Alving AS. Status of primaquine. III. Toxicity of primaquine in Caucasians. JAMA 1952; 149:1563-1568.

38. Finch CA. Methemoglobinemia and sulfhemoglobinemia. N Engl J Med 1948; 239: 470-8.

39. Fletcher KA, Evans DA, Gilles HM, Greaves J, Bunnag D, Harinasuta T. Studies on the pharmacokinetics of primaquine. Bull World Health Organ. 1981; 59: 407-12.

40. Fryauff DJ, Baird JK, Basri H, Sumawinata I, Purnomo, Richie TL, Ohrt CK, Mouzin E, Church CJ, Richards AL, et al. Randomised placebo-controlled trial of primaquine for prophylaxis of falciparum and vivax malaria. Lancet. 1995; 346: 1190-3.

41. Baird JK, Lacy MD, Basri H, Barcus MJ, Maguire JD, Bangs MJ, Gramzinski R, Sismadi P, Krisin, Ling J, Wiady I, Kusumaningsih M, Jones TR, Fryauff DJ, Hoffman SL; United States Naval Medical Research Unit 2 Clinical Trials Team. Randomized, parallel placebo-controlled trial of primaquine for malaria prophylaxis in Papua, Indonesia. Clin Infect Dis. 2001; 33: 1990-7.

42. Lacerda MVG, Llanos-Cuentas A, Krudsood S, Lon C, Saunders DL, Mohammed R, Yilma D, Batista Pereira D, Espino FEJ, Mia RZ, Chuquiyauri R, Val F, Casapía M, Monteiro WM, Brito MAM, Costa MRF, Buathong N, Noedl H, Diro E, Getie S, Wubie KM, Abdissa A, Zeynudin A, Abebe C, Tada MS, Brand F, Beck HP, Angus B, Duparc S, Kleim JP, Kellam LM, Rousell VM, Jones SW, Hardaker E, Mohamed K, Clover DD, Fletcher K, Breton JJ, Ugwuegbulam CO, Green JA, Koh GCKW. SingleDose Tafenoquine to Prevent Relapse of Plasmodium vivax Malaria. N Engl J Med. 2019; 380: 215-228.

43. Nelwan EJ, Ekawati LL, Tjahjono B, Setiabudy R, Sutanto I, Chand K, Ekasari T, Djoko D, Basri H, Taylor WR, Duparc S, Subekti D, Elyazar I, Noviyanti R, Sudoyo H, Baird JK. Randomized trial of primaquine hypnozoitocidal efficacy when administered with artemisinin-combined blood schizontocides for radical cure of Plasmodium vivax in Indonesia. BMC Med. 2015; 13: 294.Legends to FiguresFigure 1. Haemoglobin - methaemoglobin interconversion. The major factor contributing to reduction of methaemoglobin back to haemoglobin is the activity of the red cell NADH cytochrome B5 MetHb reductase. MetHb: methaemoglobin.

Figure 2: The figures show increasing levels of methaemoglobinaemia (as a proportion of the corresponding haemoglobin concentration) during radical curative treatment of vivax malaria with primaquine. On the left (Figure 2A) primaquine 30mg base/day was given to adults for 14 days either concurrently with quinine, or 28 days after a treatment dose of dihydroartemisinin-piperaquine (from Sutanto et al (21)). On the right (Figure 2B) primaquine was given to adults and children either at a dose of $0.5 \mathrm{mg}$ base $/ \mathrm{kg} /$ day for 14 days or $1 \mathrm{mg} / \mathrm{kg} /$ day for 7 days and patients were randomized to receive concurrent chloroquine or dihydroartemisinin-piperaquine (from Chu et al (22))

Figure 3: During the clinical investigations, conducted over 70 years ago in the USA, to develop new 8aminoquinolines 18 different compounds were evaluated in addition to pamaquine, and later primaquine (23-25). Each was administered for 14 days concurrently with quinine. The volunteers were infected by multiple bites of $A$. quadrimaculatusinfected with the Chesson strain of $P$. vivax. The figure shows the relationship between the radical cure proportion and the average blood methaemoglobin concentration (\%) measured in the last 4 days of treatment. The size of the circles is proportional to the number recruited as shown in the inset box.

Figure 4: Dose-response relationships for primaquine and tafenoquine in generating methaemoglobinaemia $(21,22,24-26,28-32)$. The dose shown is the daily adult dose of primaquine, whereas for tafenoquine the dose shown is the total dose administered. The size of the circles is proportional to the number of patients or volunteers recruited as shown in the inset box.

Figure 5: Studies conducted during the development of primaquine which assessed the average methaemoglobin concentration (\%) as a proportion of the haemoglobin concentration in the last 4 days 
of treatment in relation to the dosing of plasmoquine (pamaquine) (left) and primaquine (right) $(11,33,37)$. These initial observations suggested that methaemoglobinaemia following primaquine, but not plasmoquine, was attenuated by concomitant administration of chloroquine or quinine. However, later studies (summarized in Figure 6) did not confirm this. The size of the circles is proportional to the number of patients or volunteers recruited as shown in the inset box.

Figure 6: More recent studies in which methaemoglobinaemia has been assessed after different dose regimens of primaquine whether given alone $(26,39-41)$, or in combination with antimalarial drugs $(18,34$, $37,38)$, either to healthy volunteers, in antimalarial prophylaxis, or in the treatment of vivax malaria $(15,19,21,22,24-26,28-32,37,42,43)$. These do not suggest attenuation of primaquine induced methaemoglobinaemia by concomitant antimalarial drugs (as reported by Clayman et al (37)), nor are there differences between healthy subjects and patients with malaria. The size of the circles is proportional to the number of patients or volunteers recruited as shown in the inset box.

Figure 7: Mean values of haemoglobin (g/dL) and methaemoglobin (\%) in 12 normal and 12 African AG6PD deficient volunteers given primaquine (from Brewer et al (26)).

\section{Hosted file}

MetHb review figure1.pptx available at https://authorea.com/users/312614/articles/549411methaemoglobinaemia-and-the-radical-curative-efficacy-of-8-aminoquinoline-antimalarials

\section{Hosted file}

Fig 2A.pptx available at https://authorea.com/users/312614/articles/549411methaemoglobinaemia-and-the-radical-curative-efficacy-of-8-aminoquinoline-antimalarials

\section{Hosted file}

Fig 2B.pptx available at https://authorea.com/users/312614/articles/549411methaemoglobinaemia-and-the-radical-curative-efficacy-of-8-aminoquinoline-antimalarials

\section{Hosted file}

Fig 3.pptx available at https://authorea.com/users/312614/articles/549411methaemoglobinaemia-and-the-radical-curative-efficacy-of-8-aminoquinoline-antimalarials

\section{Hosted file}

Fig 4.pptx available at https://authorea.com/users/312614/articles/549411methaemoglobinaemia-and-the-radical-curative-efficacy-of-8-aminoquinoline-antimalarials

\section{Hosted file}

Fig 5A.pptx available at https://authorea.com/users/312614/articles/549411methaemoglobinaemia-and-the-radical-curative-efficacy-of-8-aminoquinoline-antimalarials

\section{Hosted file}

Fig 5B.pptx available at https://authorea.com/users/312614/articles/549411methaemoglobinaemia-and-the-radical-curative-efficacy-of-8-aminoquinoline-antimalarials

\section{Hosted file}

Fig 6.pptx available at https://authorea.com/users/312614/articles/549411methaemoglobinaemia-and-the-radical-curative-efficacy-of-8-aminoquinoline-antimalarials

\section{Hosted file}

Fig 7.pptx available at https://authorea.com/users/312614/articles/549411methaemoglobinaemia-and-the-radical-curative-efficacy-of-8-aminoquinoline-antimalarials 